\title{
Size and homology of the genomes of leprosy-derived corynebacteria, Mycobacterium leprae, and other corynebacteria and mycobacteria
}

\author{
I. ANTOINE, M. COENE and C. COCITO
}

\section{Microbiology and Genetics Unit, ICP, University of Louvain, Medical School, Brussels 1200, Belgium}

\begin{abstract}
Summary. The genomes of Mycobacterium leprae and leprosy-derived corynebacteria (LDC), which have a similar base composition of guanine + cytosine $56 \mathrm{~mol} \%$, have been compared with those of reference bacteria of the CMN group (genera Corynebacterium, Mycobacterium, Nocardia). Genome sizes of three LDC strains were $(1 \cdot 2-2 \cdot 5) \times 10^{6}$ base pairs. DNA from four of seven LDC strains examined had homology levels $>60 \%$. Two other strains had a homology of $40 \%$ when compared with the CMN strains and one strain was distinctly different. The DNA from all seven LDC strains gave $0 \cdot 3-18 \%$ hybridisation with that of $M$. leprae, 5-16\% with reference corynebacteria, 5-12\% with $M$. bovis, and 2-8\% with Nocardia caviae. The small size of the LDC genome and its unrelatedness to those of $M$. leprae and organisms of the CMN group shows the uniqueness of LDC.
\end{abstract}

\section{Introduction}

Two types of micro-organisms have been found in leprosy lesions (Cocito and Delville, 1983, 1985). Those are Mycobacterium leprae, the causative agent of the disease, and diphtheroid organisms which have been isolated from the skin and blood of leprosy patients (Beaman et al., 1974; Delville and Pichel, 1975). $M$. leprae can, at present, be cultivated only in nine-banded armadillos and in conventional or nude mice. The diphtheroids, which are not acid-fast, can be grown in pure culture and have recently been identified as corynebacteria by the presence of corynomycolic acid (Janczura et al., 1981a; Gailly et al., 1982) and a DNA base composition of guanosine + cytosine $(\mathrm{G}+\mathrm{C}) 56 \mathrm{~mol} \%$ (Danhaive et al., 1982). These organisms have been designated "leprosy-derived corynebacteria" (LDC) (Cocito and Delville, 1983). Another kind of unusual bacteria has been isolated from armadillos in the wild and in captivity, whether or not they had been inoculated with leproma homogenates (Portaels et al., 1985). These have recently been identified as mycobacteria by the presence of mycolic acid (Portaels et al., 1986) and a DNA base composition of $\mathrm{G}+\mathrm{C}$ 62-67 mol \% (De Kesel et al., 1987).

$M$. leprae has several unusual features. Its

Received 21 Dec. 1987; accepted 11 Feb. 1988. peptidoglycan differs from that of bacteria of the genera Corynebacterium, Mycobacterium, Nocardia (CMN group), in that the L-lysine is replaced by glycine (Draper, 1976). In addition, its genome size is $1.3 \times 10^{9}$ base pairs (bp) (Imaeda et al., 1982), or $2.2 \times 10^{9}$ bp (Clark-Curtiss et al., 1985), and this is smaller than that of most bacteria. Moreover, the base composition of $M$. leprae DNA is $\mathrm{G}+\mathrm{C} 56$ mol \% (Imaeda et al., 1982) whereas that of other mycobacteria is $\mathrm{G}+\mathrm{C} 62-70 \mathrm{~mol} \%$ (Barksdale and Kim, 1977; Goodfellow and Wayne, 1982).

LDC share two diagnostic characteristics with conventional corynebacteria. Their mycolic acids are of the corynomycolic type (Gailly et al., 1982) and their DNA base composition is $\mathrm{G}+\mathrm{C} 56 \mathrm{~mol}$ $\%$ (Barksdale, 1970; Danhaive et al., 1982). However, LDC have certain specific characteristics that differ from those of reference corynebacteria. Their peptidoglycan muramate is glycolylated (Janczura et al., 1981b), tuberculostearic acid is present (Brown et al., 1984), and the GATC sequences in their DNA contain $\mathrm{N}^{6}$-methyl-adenine (Hottat $e t$ al., 1987). LDC are immunologically more closely related to $M$. vaccae, $M$. nonchromogenicum, $M$. bovis and other mycobacteria, than to C. diphtheriae, C. hoffmannii, $C$. xerosis and other corynebacteria (Ridell, 1977; Laub et al., 1978; Gueur et al., 1983; Abou-Zeid et al., 1985).

The aim of the present work was to compare the genomes of leprosy-derived corynebacteria, $M$. leprae and reference bacteria of the $\mathrm{CMN}$ group. 


\section{Materials and methods}

\section{Micro-organisms}

Leprosy-derived corynebacteria strains LDC 3 and 4 were originally isolated by J. Delville (University of Louvain, Brussels) from the blood of patients with borderline and tuberculoid cases of leprosy in Zaïre. LDC $8,11,15$ and 24 were isolated by J. Delville and $\mathbf{L}$. Barksdale (New York University, New York) from skin lesions of patients with lepromatous leprosy in Zaïre, Ethiopia, and the USA (table I). Some of these strains are deposited at the American Type Culture Collection (reference numbers in table I). LDC strain A5 and $M$. leprae were isolated by $\mathrm{J}$. Delville from armadillos experimentally infected with material from lepromatous granulomas. Reference type strains were: $C$. diphtheriae PW8 from D. E. Minnikin (University of Newcastle upon Tyne), $C$. xerosis NCTC 9755, $M$. bovis BCG (Pasteur Institute, Paris), N. caviae ATCC 14629.

LDC strains and CMN organisms were grown in pure culture, in modified Dubos medium (Cocito and Delville, 1985 ) supplemented with $10 \%$ calf serum, under forced aeration in rotatory shakers. Armadillo-grown $M$. leprae (Kirchheimer and Storrs, 1971) was purified as reported by Draper (1976) and provided by the leprosy section of WHO.

\section{DNA purification}

Suspensions of bacteria $(10 \mathrm{mg})$ in $0.5 \mathrm{ml}$ of $100 \mathrm{~mm}$ $\mathrm{NaCl}, 1 \mathrm{~mm}$ ethylenediaminetetraacetate (EDTA), 50 mM Tris (hydroxy-methyl) aminomethane buffer (pH 7.8) were incubated sequentially with $25 \mu \mathrm{l}$ of lysozyme (20 $\left.\mathrm{mg} / \mathrm{ml}, 14 \mathrm{~h}, 50^{\circ} \mathrm{C}\right), 25 \mu \mathrm{l}$ of pronase $(20 \mathrm{mg} / \mathrm{ml}, 1 \mathrm{~h}$, $\left.37^{\circ} \mathrm{C}\right)$ and $25 \mu \mathrm{l}$ of sodium dodecyl sulphate $(20 \%, 1 \mathrm{~h}$, $37^{\circ} \mathrm{C}$ ). The mixtures were extracted with chloroform: isoamyl alcohol $(24: 1, \mathrm{v}: \mathrm{v})$, water-saturated phenol and ether. After incubation with $5 \mu \mathrm{l}$ of ribonuclease $\left(2 \mathrm{mg} / \mathrm{ml}, 1 \mathrm{~h}, 37^{\circ} \mathrm{C}\right)$, DNA solutions were purified by exclusion gel chromatography (Sephadex G50 columns equilibrated with $4.8 \mathrm{~mm}$ sodium phosphate $\mathrm{pH} \mathrm{7.8)}$. Void volume fractions were purified on hydroxyapatite columns, which were washed first with $8 \mathrm{M}$ urea, $0.1 \mathrm{M}$ sodium phosphate buffer ( $\mathrm{pH} 7 \cdot 8$ ) containing sodium dodecyl sulphate $1 \%$, and then with $4.8 \mathrm{~mm}$ sodium phosphate (pH 7.8). Columns were eluted with $480 \mathrm{~mm}$ sodium phosphate (pH 7.8) (De Kesel et al., 1987; Hottat et al., 1987).

\section{DNA hybridisation in liquid medium}

The two DNA species to be annealed were sonicated for $30 \mathrm{~s}$ at $60 \mathrm{~W}$ (B12 sonifier; Branson Sonic Power Co., Danbury, CT, USA) in ice. DNA segments had an average size of $10^{3}$ base pairs as determined by electrophoresis in agarose gels with Hind III-cleaved phage $\lambda$-DNA as reference. One DNA species $(0.02 \mu \mathrm{g}$ in $10 \mu \mathrm{l}$ of $0.1 \mathrm{~mm}$ EDTA plus $10 \mathrm{~mm}$ Tris hydrochloride, $\mathrm{pH} 7 \cdot 4$ ) was labelled by nick translation (Coene and Cocito, 1985), with a precursor mixture of dGTP, dTTP, and dCTP $\left(5.25 \mu \mathrm{M}\right.$ each) plus $0.166 \mu \mathrm{M}\left(\alpha-{ }^{32} \mathrm{P}\right) \mathrm{dATP}$ (3200 Ci/mmol, $3 \cdot 1 \times 10^{-3} \mu \mathrm{mol} / \mathrm{ml}$ ). The reaction was started by addition of polymerase I ( $15 \mathrm{U} / \mu \mathrm{g}$ of DNA $)$ in $1 \mathrm{~mm}$ dithiothreitol, $10 \mathrm{mM} \mathrm{MgCl}_{2}, 50 \mathrm{mM}$ Tris hydrochloride buffer $(\mathrm{pH} 7.5)$. The reaction was stopped by immersing the reaction tube at $100^{\circ} \mathrm{C}$ for $10 \mathrm{~min}$. The average specific activity of the probes was $5 \times 10^{7} \mathrm{dpm} /$ $\mu \mathrm{g}$ of DNA. A 75-fold excess of unlabelled DNA $(1.5 \mu \mathrm{g} /$ $62 \mu \mathrm{l})$ was added and the mixture was denatured by heating at $100^{\circ} \mathrm{C}$ for $10 \mathrm{~min}$. The final concentration of $\mathrm{NaCl}$ was increased to $0.3 \mathrm{M}$, and the mixture was incubated at the annealing temperature $\mathrm{t}^{\circ}=\mathrm{T}^{\mathrm{av}}{ }_{\mathrm{m}}-$ $25^{\circ} \mathrm{C}=71^{\circ} \mathrm{C}$, where $\mathrm{Tm}$ is the midpoint hyperchromic

Table I. Origins of micro-organisms analysed

\begin{tabular}{|c|c|c|c|c|}
\hline \multirow{2}{*}{$\begin{array}{l}\text { Strain } \\
\text { designation }\end{array}$} & \multicolumn{4}{|c|}{ Origin } \\
\hline & Tissue & Type of leprosy & Country & Strain no. \\
\hline LDC 3 (D40) & blood & borderline leprosy & Zaire & ATCC 35517 \\
\hline LDC 4 (D43) & blood & tuberculoid leprosy & Zaire & ATCC 35518 \\
\hline LDC $8(\mathrm{~L} 3)$ & skin & lepromatous leprosy & Zaire & ATCC 35521 \\
\hline LDC $11(0122)$ & skin & lepromatous leprosy & Zaire & - \\
\hline LDC 15 (D86) & skin & lepromatous leprosy & Ethiopia & - \\
\hline LDC 24 (2628) & skin & lepromatous leprosy & USA & ATCC 35693 \\
\hline \multicolumn{5}{|c|}{ armadillo inoculated with lepromatous granuloma } \\
\hline LDC-A5 & \multicolumn{4}{|c|}{$\begin{array}{l}\text { armadillo inoculated with lepromatous granuloma } \\
\text { armadillo inoculated with lepromatous granuloma }\end{array}$} \\
\hline \multicolumn{5}{|c|}{ Escherichia coli (strain A19) (Max-Planck Institute, Berlin Germany) } \\
\hline \multicolumn{5}{|c|}{ Corynebacterium diphtheriae (strain PW8) (D. E. Minnikin, Newcastle-upon-Tyne) } \\
\hline \multicolumn{4}{|c|}{ Corynebacterium xerosis } & NCTC 9755 \\
\hline \multirow{2}{*}{\multicolumn{4}{|c|}{$\begin{array}{l}\text { Mycobacterium bovis (BCG) (Pasteur Institute, Paris, France) } \\
\text { Nocardia caviae }\end{array}$}} & ATCC 14629 \\
\hline & & & & ATCC 14629 \\
\hline
\end{tabular}


transition at $260 \mathrm{~nm}$ of the DNA melting curve and $\mathrm{T}^{\mathrm{av}}{ }_{\mathrm{m}}$ was the average of the $T_{m}$ values of the two DNAs to be annealed (Baess and Bentzon, 1978; Baess, 1979). The $T_{m}$ value of a given DNA was calculated from its $G+C$ content according to the relation $T_{m}=69.3+0.41(G+$ C) $+18.5 \log \mathrm{M}$, where $\mathrm{M}$ was the ratio of the $\mathrm{NaCl}$ concentrations of the unknown DNA $(0 \cdot 3 \mathrm{M}$ in this case) and of reference DNA (that of E. coli, the $\mathrm{T}_{\mathrm{m}}$ of which was determined in $0.195 \mathrm{M} \mathrm{NaCl}$ ) (Dove and Davidson, 1962). The length of the annealing reaction was made equal to twice the Cot $1 / 2$ value (Johnson, 1985) of the product of the single-stranded DNA concentration (moles of nucleotides $/ \mathrm{L}$ ) and the time in seconds required to render half of the input DNA double-stranded. DNA mixtures hybridised under stringent conditions were incubated with $\mathrm{S} 1$ nuclease ( $5 \mathrm{U} / \mu \mathrm{g}$ of DNA) for $30 \mathrm{~min}$ at $37^{\circ} \mathrm{C}$ (De Kesel et al., 1987). Nuclease buffer contained $0.045 \mathrm{M} \mathrm{NaCl}, 0.033 \mathrm{M}$ sodium acetate ( $\mathrm{pH} 4.5$ ), and $3 \times$ $10^{-4} \mathrm{M} \mathrm{ZnSO}_{4}$. Hydrolysis was stopped by adding $1 \mathrm{ml}$ of ice-cold $10 \mathrm{mM}$ EDTA, $10 \mathrm{mM}$ Tris hydrochloride buffer ( $\mathrm{pH} \mathrm{7.4)}$ followed by $2 \mathrm{ml} \mathrm{of} 10 \%$ trichloroacetic acid containing serum albumin $0.02 \%$. After $30 \mathrm{~min}$ in ice, mixtures were filtered through glass fibre filters and counted in a scintillation counter. For each experiment, several controls were included. Homologous DNA reassociation, which varied between 60 and $90 \%$ of the input, was taken as $100 \%$ hybridisation. A blank sample was prepared with an unrelated DNA of $\mathrm{G}+\mathrm{C}$ content close to that of the unknown sample, in this case Escherichia coli DNA. In addition, kinetics of single- and doublestranded DNA hydrolysis by S1 nuclease, under our experimental conditions, were monitored for each annealing DNA. The optimum concentration giving $89 \%$ digestion of single-stranded DNA and $9.8 \%$ cleavage of the double-stranded species was found to be 5 enzyme units of S1 endonuclease per $\mu \mathrm{g}$ of DNA (De Kesel et al., 1987).

\section{Measurement of genome size}

The size of labelled LDC DNA was measured at $71{ }^{\circ} \mathrm{C}$ by analysis of renaturation kinetics (De Ley et al., 1970; Baess and Mansa, 1978). The Cot $1 / 2$ value of the product of the initial concentration of denatured DNA (moles of nucleotides $/ \mathrm{L}$ ) and the time (s) giving $50 \%$ re-annealing, was determined by graphic interpolation from the kinetic plots (Britten and Kohne, 1968; McFadden et al., 1987). The technique used was similar to that outlined above, except that samples were periodically withdrawn from the reaction mixture for incubation with $\mathrm{S} 1$ nuclease. The enzyme action was stopped by addition of ice-cold trichloroacetic acid and, after filtration, the radioactivity of residual labelled DNA was measured. For this purpose, air-dried glass-fibre filters (MN85; Machery-Nagel, Düren, FRG) in a mixture containing Omnifluor (New England Nuclear) $4 \mathrm{~g} / \mathrm{L}$ of toluene were counted in a scintillation counter. The Cot $1 / 2$ value was calculated by linear regression from 12 measurements and the correlation coefficient was $>0.97$.

\section{Results}

\section{Size of LDC genomes}

Genome size for three LDC strains was determined by renaturation kinetics of fragmented DNA preparations of an average size of $10^{3}$ base pairs. The figure shows the reassociation kinetics of the DNA obtained from LDC strains, compared with that of reference DNA from $E$. coli. The latter had a Cot $1 / 2$ value of 1.123 and the corresponding values for LDC 15, 4 and A5 were $0.683,0.563$ and $0 \cdot 312$, respectively. The reassociation kinetics of three LDC strains are summarised in table II. They show that the LDC genomes were smaller than that of $E$. coli $\left(4.2 \times 10^{6} \mathrm{bp}\right)$. The values for DNA of LDC were in the range $(1 \cdot 2-2 \cdot 5) \times 10^{6} \mathrm{bp}$.

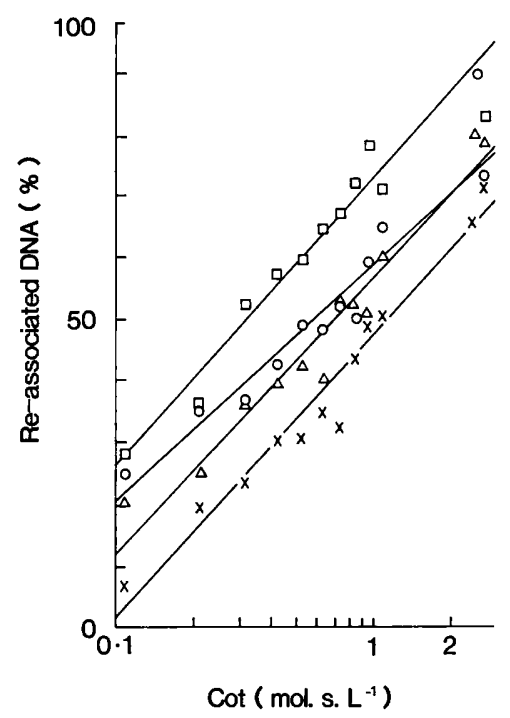

Figure. Kinetics of single-stranded DNA reassociation. Four samples of denatured bacterial DNA were re-annealed at $71^{\circ} \mathrm{C}$, and reassociation kinetics was recorded as detailed in Materials and methods. Sources of DNA: E. coli (-x-), LDC 15 $(-\triangle-), \operatorname{LDC} 4(-\mathrm{O}-)$ and LDC A5 (- $\square-)$.

Table II. Renaturation properties of DNA from LDC and $E$. coli

\begin{tabular}{lcc}
\hline Test strain & Cot $1 / 2^{*}$ & $\begin{array}{c}\text { Genome size } \\
\left(\mathrm{bp} \times 10^{6}\right)\end{array}$ \\
\hline E. coli & $1 \cdot 123$ & 4.20 \\
LDC 15 & 0.663 & 2.48 \\
LDC 4 & 0.563 & 2.11 \\
LDC A5 & 0.312 & $1 \cdot 17$ \\
\hline
\end{tabular}

* The Cot $1 / 2$ value was obtained by linear regression from 12 determinations with correlation coefficients higher than 0.97 . 


\section{Homology amongst LDC genomes}

Homologous and heterologous hybridisation of the genomes of LDC and $M$. leprae was made to explore their genetic relatedness. Table III shows that LDC strains 3, 4, 8 and A5 were very similar to each other with hybridisation values of $63.1-$ $87 \cdot 1 \%$. The degree of homology of LDC 11 and 24 , was lower than that of the preceding strains at 38$48 \%$. LDC 15 was different. No LDC strain was similar to $M$. leprae with homologies of $0 \cdot 3-18 \%$.

\section{Genetic relatedness of $L D C$ and $C M N$ organisms}

To clarify the taxonomic position of LDC strains, their DNA was hybridised with those of reference CMN organisms. Table IIIB shows that there was homology of only $5-16 \%$ between three LDC strains and the two reference corynebacteria. LDC showed little homology with $M$. bovis and $N$. caviae. Among reference $\mathrm{CMN}$ bacteria, only $M$. bovis BCG was $46.6 \%$ homologous with $M$. leprae.

\section{Discussion}

The small genome of $M$. leprae (Clark-Curtiss et al., 1985) may be due to the deletion of genes leading to nutritional deficiencies, which account for its inability to grow in vitro. Similar reasons may account for the inability of LDC, with genome sizes of $(1 \cdot 2-2 \cdot 5) \times 10^{6} \mathrm{bp}$, to grow in defined media without serum supplements (Cocito and Deville, 1985).

LDC appear to be immunologically related to $M$. leprae. Indeed, sera from leprosy patients can recognise both organisms (Laub et al., 1978). This relationship is accounted for by the cross-reactivity of $M$. leprae antigen 7 with the corresponding antigen $\mathrm{M} 1$ that is present in the cytoplasm and all wall of LDC (Gueur et al., 1983). The unexpected finding that the genomes of LDC and $M$. leprae have similar base composition (G+C c. $56 \mathrm{~mol} \%$ ) (Danhaive et al., 1982; Imaeda et al., 1982; Hottat et al., 1987) suggests that this may be reflected in a relationship at the genetic level. Although extensive homology between one LDC strain and $M$. leprae has previously been noted (Imaeda et al., 1982), much lower hybridisation values were subsequently reported by the same authors (Athwal et al., 1984). The results presented in table III show very limited hybridisation between the DNA of seven LDC strains and $M$. leprae. Since we have recently suggested that there is no homology between $M$. leprae and $\mathrm{ADM}$, it can be inferred that $M$. leprae, LDC and ADM are genetically unrelated (De Kesel et al., 1987; Hottat et al., 1987 and unpublished results).

Previous work from our laboratory has shown that LDC strains, though having the characteristics of corynebacteria, because of the presence of cellwall corynomycolic acid (Gailly et al., 1982) and of DNA with G + C 56 mol \% (Danhaive et al., 1982),

Table III. Homology of the genomes of LDC, $M$. leprae and reference bacteria

\begin{tabular}{|c|c|c|c|c|}
\hline \multirow{2}{*}{$\begin{array}{l}\text { Unlabelled DNA- } \\
\text { source }\end{array}$} & \multicolumn{4}{|c|}{ Relative hybridisations (mean $\pm \mathrm{SEM} \%$ )* with labelled DNA from } \\
\hline & LDC 15 & $\mathbf{L D C ~} \mathbf{A}_{5}$ & LDC 4 & M. leprae \\
\hline $\begin{array}{l}\text { A } \\
M . \text { leprae } \\
\text { LDC } 3 \\
\text { LDC } 4 \\
\text { LDC } 8 \\
\text { LDC } 11 \\
\text { LDC } 15 \\
\text { LDC } 24 \\
\text { LDC A }\end{array}$ & $\begin{array}{c}0 \\
4 \cdot 1 \pm 2 \cdot 6 \\
6 \cdot 5 \pm 1 \cdot 8 \\
9 \cdot 6 \pm 4 \cdot 7 \\
9 \cdot 7 \pm 5 \cdot 3 \\
100 \\
3 \cdot 6 \pm 5 \cdot 1 \\
4 \cdot 7 \pm 5 \cdot 7\end{array}$ & $\begin{array}{c}0 \\
70 \cdot 8 \pm 14 \cdot 4 \\
75 \cdot 4 \pm 9 \cdot 6 \\
63 \cdot 1 \pm 7 \cdot 6 \\
48 \cdot 0 \pm 5 \cdot 7 \\
12 \cdot 3 \pm 3 \cdot 7 \\
37 \cdot 8 \pm 16 \cdot 0 \\
100\end{array}$ & $\begin{array}{c}0 \\
87 \cdot 1 \pm 1 \cdot 3 \\
100 \\
71 \cdot 5 \pm 1 \cdot 1 \\
46 \cdot 6 \pm 5 \cdot 3 \\
13 \cdot 6 \pm 2 \cdot 8 \\
43 \cdot 5 \pm 19 \\
75 \cdot 0 \pm 1 \cdot 1\end{array}$ & $\begin{array}{c}100 \\
2 \cdot 8 \pm 4 \cdot 0 \\
6 \cdot 4 \pm 9 \cdot 1 \\
8 \cdot 8 \pm 6 \cdot 0 \\
14 \cdot 0 \pm 11 \cdot 5 \\
8 \cdot 3 \pm 7 \cdot 1 \\
17 \cdot 9 \pm 24 \cdot 2 \\
0 \cdot 3 \pm 0 \cdot 4\end{array}$ \\
\hline B & & & & \\
\hline $\begin{array}{l}\text { C. diphtheriae } \\
\text { C. xerosis } \\
\text { M. bovis } \mathrm{BCG} \\
N \text {. caviae } \\
\text { E. coli }\end{array}$ & $\begin{array}{l}7 \cdot 7 \pm 1 \cdot 4 \\
5 \cdot 2 \pm 0 \cdot 04 \\
8 \cdot 4 \pm 3 \cdot 1 \\
3 \cdot 0 \pm 4 \cdot 2 \\
\quad 0\end{array}$ & $\begin{array}{c}12 \cdot 2 \pm 1 \cdot 9 \\
16 \cdot 5 \pm 3 \cdot 2 \\
12 \cdot 3 \pm 5 \cdot 0 \\
8 \cdot 2 \pm 7 \cdot 5 \\
0\end{array}$ & $\begin{array}{r}5 \cdot 2 \pm 6 \cdot 7 \\
11 \cdot 0 \pm 3 \cdot 2 \\
5 \cdot 1 \pm 4 \cdot 7 \\
1 \cdot 8 \pm 0 \cdot 7 \\
0\end{array}$ & $\begin{array}{c}21 \cdot 7 \pm 9 \cdot 2 \\
9.2 \pm 1 \cdot 4 \\
46 \cdot 6 \pm 17 \cdot 0 \\
7 \cdot 7 \pm 0.8 \\
0\end{array}$ \\
\hline
\end{tabular}

* Each experiment was performed at least three times. 
cross-reacted immunologically with mycobacteria rather than with Corynebacterium spp. (Ridell, 1977; Laub et al., 1978). These observations and the lack of genetic relatedness between LDC and reference corynebacteria (table III) have rendered the taxonomic position of LDC uncertain. The taxonomic position of $M$. leprae is also rendered uncertain by a base content of $\mathrm{G}+\mathrm{C} 56 \mathrm{~mol} \%$ (Imaeda et al., 1982; Hottat et al., 1987) rather than 62-70 mol \% of typical mycobacterial DNA, and replacement of $\mathrm{L}$-alanine by glycine in the tetrapeptide of peptidoglycan (Draper, 1976).

We have reported previously the homogeneity of the LDC group. Isolates from patients worldwide had similar cell-wall composition, immunological properties and DNA base composition (Danhaive et al., 1982; Cocito and Delville, 1983). This

\section{REFERENCES}

Abou-Zeid C, Harboe M, Sundsten B, Cocito C 1985 Crossreactivity of antigens from the cytoplasm and cell walls of some corynebacteria and mycobacteria. Journal of Infectious Diseases 151 : 170-178

Athwal R S, Deo S S, Imaeda T 1984 Deoxyribonucleic acid relatedness among Mycobacterium leprae, Mycobacterium lepraemurium and selected bacteria by dot blot and spectrophotometric deoxyribonucleic acid hydridization assays. International Journal of Systematic Bacteriology 34: 371-375.

Baess I 1979 Deoxyribonucleic acid relatedness among species of slowly-growing mycobacteria. Acta Pathologica et Microbiologica Scandinavica Section B87: 221-226.

Baess I, Mansa B 1978 Determination of genome size and base ratio on deoxyribonucleic acid from mycobacteria. Acta Pathologica et Microbiologica Scandinavica Section B87: 309-312.

Baess I, Bentzon M W 1978 Deoxyribonucleic acid hybridization between different species of mycobacteria. Acta Pathologica et Microbiologica Scandinavica Section B86: $71-$ 76.

Barksdale L 1970 Corynebacterium diphtheriae and its relatives. Bacteriological Reviews 34: 378-422.

Barksdale L, Kim K S 1977 Mycobacterium. Bacteriological Reviews 41 : 217-372.

Beaman B L, Kim K S, Laneelle M A, Barksdale L 1974 Chemical characterization of organisms isolated from leprosy patients. Journal of Bacteriology 117: 1320-1329.

Britten R J, Kohne D E 1968 Repeated sequences in DNA. Hundreds of thousands of copies of DNA sequences have been incorporated into the genomes of higher organisms. Science 161 : $529-540$.

Brown S, Lanelle M A, Asselineau J, Barksdale L 1984 Description of Corynebacterium tuberculostearicum sp. nov., a leprosy-derived corynebacterium. Annales de Microbiologie (Institut Pasteur) 135B: 251-267.

Cocito C, Delville J 1983 Properties of microorganisms from human leprosy lesions. Reviews of Infectious Diseases 5: 649-657.

Cocito C, Delville J 1985 Biological, chemical, immunological and staining properties of bacteria isolated from tissues of homogeneity is suggested by the presence in all LDC strains of a specific $\mathrm{GA}^{\mathrm{m}} \mathrm{TC}$ genetic marker $\left(\mathrm{A}^{\mathrm{m}}=\mathrm{N}^{6}\right.$ methyladenine $)$, in which the adenine of GATC sequences of DNA is replaced by 6-methyladenine, a feature not shared by any organisms of the CMN group tested (Hottat et al., 1987). However, the results reported have indicated some heterogeneity within the LDC group. Different isolates were found to differ in genome size (table II) and homology levels (table III).

We conclude that the genomes of LDC strains are small and that they are genetically unrelated to conventional corynebacteria and $M$. leprae. On the basis of the present and previous results, we propose that LDC, because of their unusual properties, represent a new species within the CMN group of micro-organisms.

leprosy patients. European Journal of Epidemiology 1 : 202 231.

Coene M, Cocito C 1985 A microanalytical procedure for determination of the base composition of DNA. European Journal of Biochemistry 150 : 475-479.

Clark-Curtiss J E, Jacobs W R, Dochery M A, Ritchie L R, Curtiss R 1985 Molecular analysis of DNA and construction of genomic libraries of Mycobacterium leprae. Journal of Bacteriology 161 : 1093-1102.

Danhaive P, Hoet P, Cocito C 1982 Base compositions and homologies of deoxyribonucleic acids of corynebacteria isolated from human leprosy lesions and of related microorganisms. International Journal of Systematic Bacteriology 32: 70-76

De Kesel M, Coene M, Portaels F, Cocito C 1987 Analysis of deoxyribonucleic acid from armadillo-derived mycobacteria. International Journal of Systematic Bacteriology 37: 317-322.

Delville J, Pichel A M 1975 L'agent étiologique de la lèpre est-il invariablement acido-alcoolo résistant au Ziehl-Neelsen? Problèmes soulevés par les isolements à partir de lésions lépreuses de germes non acido-alcoolo résistants. Acta Leprologica 59/60: 83-91.

De Ley J., Cattoir H, Reynaerts A 1970 The quantitative measurement of DNA hybridization from renaturation rates. European Journal of Biochemistry 12: 133-142.

Dove W F, Davidson N 1962 Cation effects of the denaturation of DNA. Journal of Molecular Biology 5 : 467-478.

Draper P 1976 Cell walls of Mycobacterium leprae. International Journal of Leprosy $44: 95-98$

Gailly C, Sandra P, Verzele M, Cocito C 1982 Analysis of mycolic acids from a group of corynebacteria by capillary gas chromatography and mass spectrometry. European Journal of Biochemistry 125 : 83-94.

Goodfellow M, Wayne L G 1982 Taxonomy and nomenclature. In: Ratledge C, Stanford J (eds) Biology of the mycobacteria. Academic Press, London, pp 471-523.

Gueur M C, Harboe M, Fontaine F, Delville J, Cocito C 1983 Comparison of the cytoplasmic antigens of leprosy-derived corynebacteria and some mycobacteria. Scandinavian Journal of Immunology 17: 497-506.

Hottat F, Coene M, Cocito C 1987 DNA methylation in leprosyassociated bacteria: Mycobacterium leprae and Corynebac- 
terium tuberculostearicum. Medical Microbiology and Immunology 176 : 33-45.

Imaeda T, Kirchheimer W F, Barksdale L 1982 DNA isolated from Mycobacterium leprae: genome size, base ratio, and homology with other related bacteria as determined by optical DNA-DNA reassociation. Journal of Bacteriology 150: 414-417.

Janczura E, Abou-Zeid C, Gailly C, Cocito C 1981 $a$ Chemical identification of some cell-wall components of microorganisms isolated from human leprosy lesions. Zentralblatt für Bakteriologie, I.Abt.Orig.A. 251: 114-125.

Janczura E, Leyh-Bouille M, Cocito C, Ghuysen J M $1981 b$ Primary structure of the wall peptidoglycan of leprosyderived corynebacteria. Journal of Bacteriology 145: 775779.

Johnson J L 1985 DNA reassociation and RNA hybridization of bacterial nucleic acids. Methods in Microbiology 18: 3373.

Kirchheimer W F, Storrs E E 1971 Attempts to establish the armadillo (Dasypus novemcinctus, Limm.) as a model for the study of leprosy. I. Report of lepromatoid leprosy in an experimentally infected armadillo. International Journal of Leprosy 39: 693-702.
Laub R, Delville J, Cocito C 1978 Immunological relatedness of ribosomes from mycobacteria, nocardiae and corynebacteria, and microorganisms in leprosy lesions. Infection and Immunity 22: 540-547.

McFadden J J, Butcher P D, Chiodini R J, Hermon-Taylor J 1987 Determination of genome size and DNA homology between an unclassified Mycobacterium species isolated from patients with Crohn's disease and other mycobacteria. Journal of General Microbiology 133: 211-214.

Portaels F, De Ridder K, Pattyn S R 1985 Cultivable mycobacteria isolated from organs of armadillos uninoculated and inoculated with Mycobacterium leprae. Annales de Microbiologie (Institut Pasteur) 136A: 181-190.

Portaels F et al. 1986 A cooperative taxonomic study of mycobacteria isolated from armadillos infected with $M y$ cobacterium leprae. Journal of General Microbiology 132: 2693-2707.

Ridell M 1977 Studies on corynebacterial precipitinogens common to mycobacteria, nocardiae and rhodochrous. International Archives of Allergy and Applied Immunology 55 : 468-475. 